\title{
THREATS IN THE WORKPLACE AS A DETERMINANT OF SHAPING THE EMPLOYEE'S ABILITY TO WORK
}

doi: $\quad 10.2478 /$ czoto-2019-0112

Date of submission of the article to the Editor: $30 / 11 / 2018$

Date of submission of the article to the Editor: 15/01/2019

\author{
Marzena Pytel-Kopczyńska ${ }^{1}$ - orcid id: 0000-0001-8850-8586 \\ Agnieszka Strzelecka ${ }^{1}$ - orcid id: 0000-0002-6030-0860 \\ Alena Daňková ${ }^{2}$ - orcid id: 0000-0002-0840-0776 \\ ${ }^{1}$ Czestochowa University of Technology, Poland, marzena.pytel-kopczynska@wz.pcz.pl. \\ agnieszka.strzelecka@wz.pcz.pl \\ ${ }^{2}$ Catholic University in Ružomberok, Slovakia
}

\begin{abstract}
The results of a literature review show that there is an undeniable link between the working conditions connected with the existence of threats in a form of harmful, dangerous (mechanical) or strenuous factors and the employees' health condition determining the level of their ability to continue their work. It is necessary to shape the employee's working environment in an appropriate way by eliminating or minimising the threats related to the work process (in accordance with the binding norms) in order to prevent the existence of any health problems or such undesirable events as accidents at work.

Thus, the issue concerning the influence of elimination or limitation of threats connected with the existence of harmful, dangerous (mechanical) and strenuous factors in the work process on the level of employment in the hazardous conditions considering the prevention of early leave from the performed work is becoming an important and current research problem. Therefore, in this article, the attempt was made to present the dependencies between the level of considered employment and the factors affecting the level of acceptable occupational risk. The econometric modelling, which uses cross-section-time data, was applied. Moreover, the analysis showing the changes in shaping considered variables was performed. The presented information refers to Polish regions and was taken from the publications of CSO (Statistics Poland) covering the period 2011 - 2017.
\end{abstract}

Keywords: threats, work process, ability to work, cross-section-time data, dynamics indicators

\section{INTRODUCTION}

The phenomenon of life extension, undoubtedly positive, contributes to the increase in the percentage of ageing labour force at the labour market. According to the forecasts of EU-OSHA, persons at the age of 55-64 will constitute almost $30 \%$ of the whole labour force (Ilmarinen, 2012). It results in the prolongation of the professional life and also in the longer time of a human exposure on hazards existing in the work place. It 
may lead to the increase in the number of employees suffering from chronic workrelated health problems, which is confirmed in the scientific literature (Takala et al., 2014; Pęciłło, 2015; Lund et al., 2006; Voss et al., 2001). Anticipating the possible numerous problems connected with the increase in the number of elder persons in the society, thus, ageing of the potential labour resources, the concept of the active ageing, based on optimising the chances connected with safety, health, employees' participation in the organisation as they are ageing so that they remain productive both for the economy and the society, should constitute the focus of interest ( $\mathrm{Ng}$ and Feldman, 2008).

In this context shaping the working environment conditions by eliminating or minimising work-related threats is becoming crucial in the long-term strategy to prevent inability to work. Thus, the purpose of this article is to analyse the influence of the elimination or limitation of hazards related to the existence of harmful, dangerous and strenuous conditions in the work process at the level of employment in hazardous conditions with the particular consideration of the prevention against premature leave from work.

\section{METHODOLOGY OF RESEARCH}

The number of persons employed in hazardous conditions was analysed in this work. Statistical analyses presented how the percentage share of persons feeling two or more complaints or having significant limitations of the ability to perform everyday activities due to the most serious complaint shaped both in the total number of persons ever working as well as in the group of persons having any complaints. The existence of health problems related to work was also analysed taking into consideration the age of employed persons. In the econometric model the number of employed persons depended on the elimination or limitation of various threats. The econometric model and the cross-section-time data were applied in a space-time analysis and the results were obtained with the use of panel model - Polish voivodeships constituted objects $(i)$ and the time $(t)$ covered years $2013-2017$. The number of persons employed in each voivodeship was the basis of comparisons. Thus, the following varieties were considered in the econometric tests to assess the number of persons employed in hazardous conditions $(P E i H C)$ :

- Persons employed in hazardous conditions in relation to whom the threats related to harmful conditions were eliminated or limited to the level complying with the norm during the year - TWE (threats-cum-persons / 1,000 persons employed in a voivodship);

- Persons employed in hazardous conditions in relation to whom the threats related to strenuous conditions were eliminated or limited to the level complying with the norm during the year - TSW (threats-cum-persons / 1,000 persons employed in a voivodship);

- Persons employed in hazardous conditions in relation to whom the threats related to dangerous (mechanical) conditions were eliminated or limited to the level complying with the norm during the year - TMF (threats-cum-persons / 1,000 persons employed in a voivodship)

After the preliminary analyses, the following model was proposed to describe the dependent variable: 


$$
P E i H C_{i t}=\ln \alpha_{0}+\alpha_{1} \ln \frac{1}{T W E_{i t}}+\alpha_{2} \ln T S W_{i t}+\alpha_{3} \ln T M F_{i t}+\varepsilon_{i t}
$$

As it can be noticed, the influence of variables is different - of TSW and TMF is logarithmic, and of TWE - hyperbolic.

Taking into consideration the influence of explanatory variables on the tested employment in particular voivodeships, dummy variables were used as the model with artificial variables, in the case of the set of particular, fixed objects, gives reliable results in the substantive and statistical sense. The ordinary least squares method (OLS) was used to estimate the model and the GRETL package was applied.

The annual data taken from the publications of the Central Statistical Office (CSO Statistics Poland) were used to analyse the issues, i.e. "Working conditions in 2013 2017", "Accidents at work and work-related health problems 2014" and databases of local CSO.

\section{RESULTS}

\subsection{Ability to work}

As it results from the reports of CSO, among the persons who were ever employed, the greatest percentage share have persons who have at least two complaints, was in Lublin Voivodeship (12.13\%), whereas the smallest percentage share was noticed in Greater Poland Voivodeship (4.75\%).

The analysis of persons who had work-related complaints provides interesting information. In this group the percentage share of persons having two or more complaints and having significant limitation of the ability to perform everyday activity due to the most serious complaint shapes at one of the highest levels in Subcarpathian Voivodeship (49.5\% and $20.6 \%$, respectively).

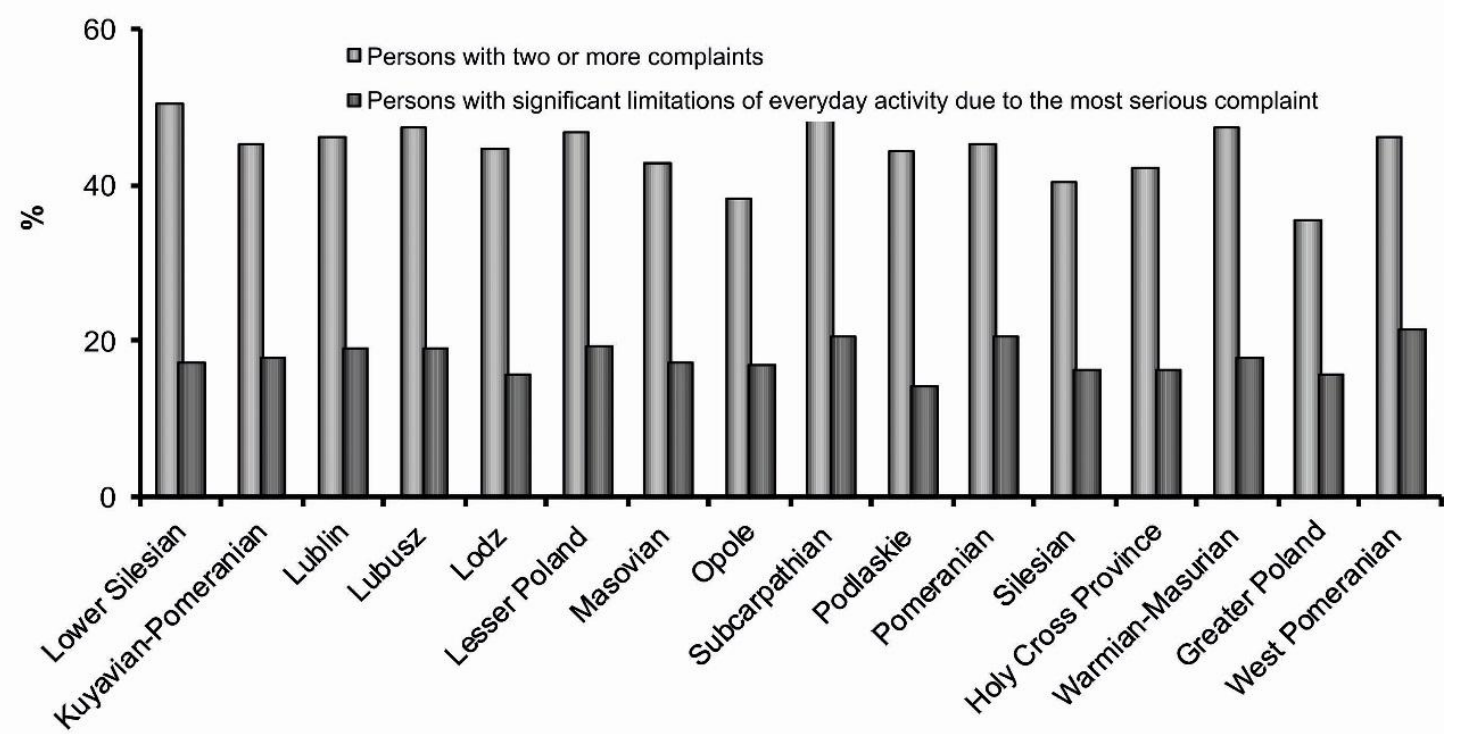

Fig. 1. Percentage share of persons who felt some health work-related complaints in the group of persons who felt health work-related complaints by voivodeships in Poland in 2014 Source: Own calculations on the basis of database-1 GUS, https://stat.gov.pl

The situation changes while analysing the smallest of the mentioned percentage shares. The persons in Wielkopolskie Voivodeship felt two or more complaints in the 
smallest rate and in relation to the group of persons with significant limitations of ability in Podlaskie Voivodeship (Fig. 1).

As it is known, the older the persons, the smaller is their ability to work and they feel more and more significant limitations of the ability to perform everyday activity due to the most serious complaint.

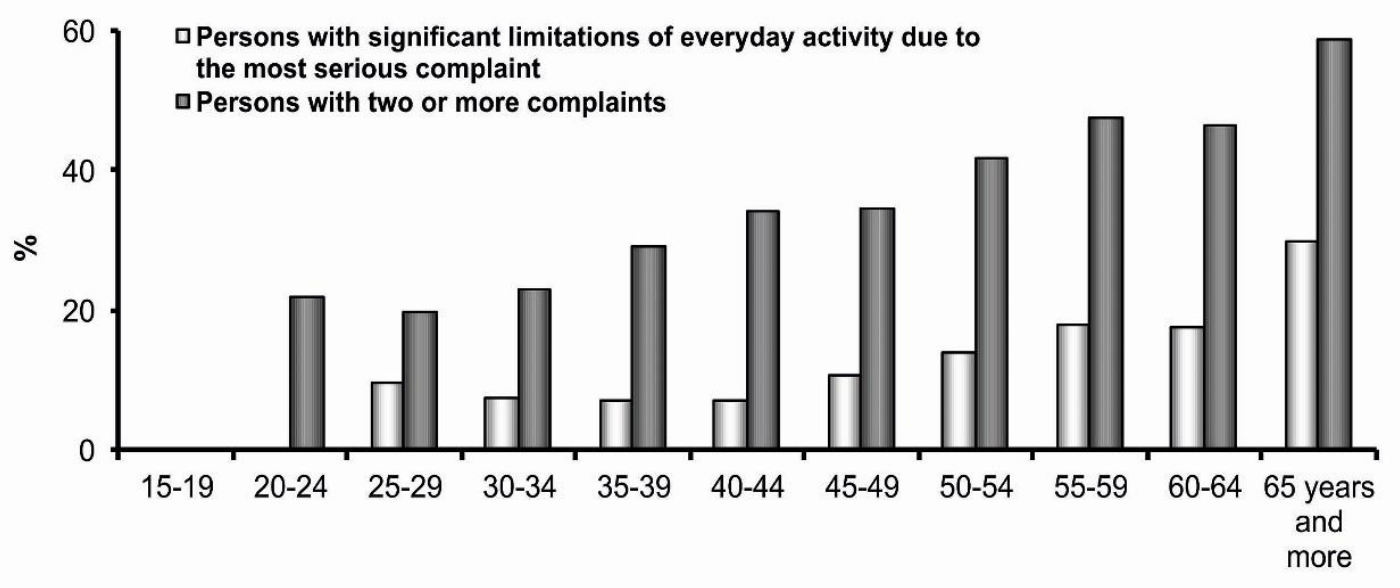

age

Fig. 2 Percentage share of persons who felt some health work-related complaints in the group of persons who felt health work-related complaints - by age in Poland in 2014

Source: Own calculations on the basis of database-1 GUS, https://stat.gov.pl

On the basis of the information presented in Figure 2, it can be stated that the age group 55 - 59 year-olds constitutes the biggest percentage share in the group of persons having work-related complaints - independently of the fact which variant is considered. Such a conclusion may be made considering the persons who did not reach the retirement age. Whereas the percentage share of persons feeling at least two complaints was increasing together with the employees' ageing and it is impossible to talk about any work-related complaints among young persons (15 - 19 years old). However, also the persons over 20 and under 24 years old may be regarded as young persons. Nevertheless, some complains are felt in this group (at the level of $21 \%$ of the percentage discussed here).

Table 1

Changes in the number of persons employed in hazardous conditions in the voivodeships in Poland in years $2013-2017$ in \% (2014=100\%)

\begin{tabular}{|l|r|r|r|r|r|}
\hline \multirow{2}{*}{ Years } & \multicolumn{1}{|c|}{$\mathbf{2 0 1 3}$} & \multicolumn{1}{|c|}{$\mathbf{2 0 1 4}$} & \multicolumn{1}{|c|}{ in \% } & \multicolumn{1}{|c|}{$\mathbf{2 0 1 6}$} & \multicolumn{1}{|c|}{} \\
\cline { 2 - 6 } Voivodeships & 106.61 & 100.00 & 92.67 & 83.13 & 82.02 \\
\hline Lower Silesian & 103.22 & 100.00 & 96.81 & 90.46 & 85.43 \\
\hline Kuyavian-Pomeranian & 111.47 & 100.00 & 90.01 & 90.20 & 86.40 \\
\hline Lublin & 117.43 & 100.00 & 97.93 & 95.82 & 100.88 \\
\hline Lubusz & 122.67 & 100.00 & 106.50 & 111.23 & 112.59 \\
\hline Lodz & \multicolumn{5}{|l}{}
\end{tabular}

In comparison with year 2014, the increase in the number of persons employed in hazardous conditions was noticed in only two voivodeships in each of the considered years. It occurred in Lodzkie and Holy Cross Provinces and this index was always 
higher in the first one. It is alarming that this difference was increasing and amounted to even 11.79 percentage point in 2017 (Table 1).

Table 2

Changes in the number of persons employed in hazardous conditions in the voivodeships in Poland in years $2013-2017$ in \% (2014=100\%) (cont.)

\begin{tabular}{|c|c|c|c|c|c|}
\hline \multirow{2}{*}{ Voivodeships } & 2013 & 2014 & 2015 & 2016 & 2017 \\
\hline & \multicolumn{5}{|c|}{ in $\%$} \\
\hline Lesser Poland & 98.73 & 100.00 & 95.47 & 80.10 & 83.38 \\
\hline Masovian & 108.15 & 100.00 & 112.73 & 97.41 & 95.17 \\
\hline Opole & 119.66 & 100.00 & 105.26 & 102.54 & 76.22 \\
\hline Subcarpathian & 102.54 & 100.00 & 102.83 & 93.13 & 91.17 \\
\hline Podlaskie & 103.39 & 100.00 & 104.58 & 96.19 & 99.01 \\
\hline Pomeranian & 107.54 & 100.00 & 99.73 & 98.67 & 93.76 \\
\hline Silesian & 102.95 & 100.00 & 95.82 & 89.78 & 87.66 \\
\hline Holy Cross Province & 107.73 & 100.00 & 102.10 & 103.05 & 100.80 \\
\hline Warmian-Masurian & 106.35 & 100.00 & 100.06 & 91.93 & 90.76 \\
\hline Greater Poland & 98.78 & 100.00 & 95.98 & 87.75 & 91.00 \\
\hline West Pomeranian & 103.21 & 100.00 & 102.85 & 100.19 & 81.29 \\
\hline
\end{tabular}

Counted only once in a group of a dominating factor.

Source: Own calculations on the basis of database-2 GUS, https://stat.gov.pl

Carrying out an in-depth analysis referring to the influence of harmful, strenuous and mechanical (dangerous) factors made it possible to notice the changes occurring in the number of persons employed in hazardous conditions in comparison to the ones towards whom the threats were eliminated or limited to the level consistent with the norm during the year.

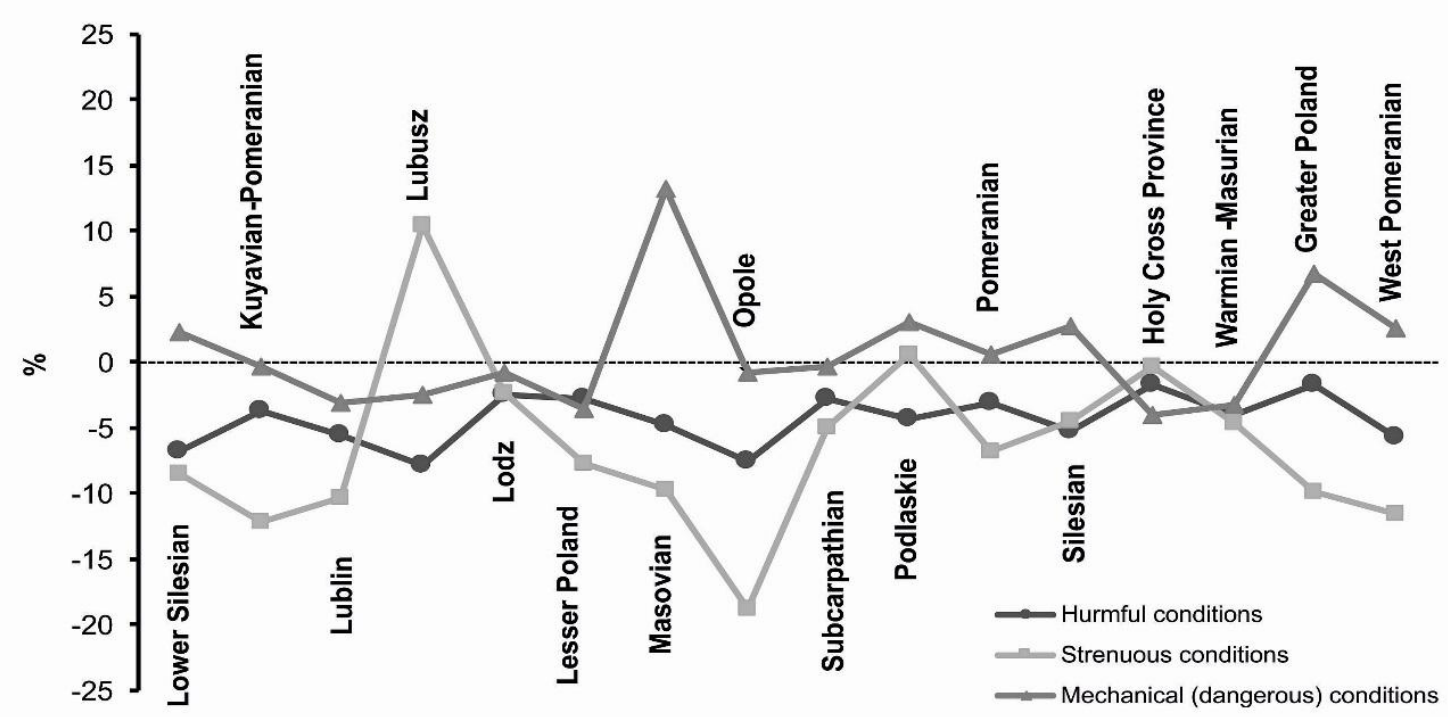

Fig. 3. Medium-term tempo of change in the number of persons employed in hazardous conditions related to various factors in voivodeships of Poland in years 2013-2017 Source: Own calculations on the basis of database-2 GUS, https://stat.gov.pl

Taking into consideration the medium-term tempo of change in the number of persons employed in hazardous conditions, when it comes to factors related to the harmful conditions, it may be noticed that this number decreased in every voivodeship. The 
decrease was the smallest in Greater Poland Voivodeship. There was a fall in the number of these employed, on average, by $1.62 \%$ year by year in this region in the whole tested period. Whereas the biggest decrease was noticed in Lubusz Voivodeship (The average tempo of changes was the lowest and amounted to $92.09 \%$.). The situation was different in the case of persons employed in strenuous working conditions. In this case, the increase by, on average, $10.4 \%$ was noticed year by year and the biggest fall was noticed in Opole Voivodeship (In years 2013-2017 the fall in the number of these employed was about $18.76 \%$ year by year in Opole Voivodeship.). Analysing the situation in Holy Cross Province, it is stated that the changes are almost unnoticeable. Medium-term tempo of change is different in the case of the number of persons employed in hazardous conditions related to dangerous (mechanical) conditions. Masovian and Greater Poland Voivodeships were leaders at the "positive" side. In the first one, this number increased, on average, by $13.2 \%$ year by year in years $2013-2017$ and in the other one by $6.69 \%$. When it comes to the decreases, the number of the persons employed in the conditions of threats related to dangerous (mechanical) conditions fell, on average, the most in Holy Cross Province $-4.04 \%$ year by year and Lesser Poland Voivodeship $-3.6 \%$ in the whole analysed period. In the group of all voivodeships, five of them showed the value of the relative increments at the level lower than $|1| \%$ - it occurred in the voivodeships: Subcarpathian, Kuyavian-Pomeranian, Opole, Lodzkie and Pomeranian. It means that the employment in hazardous conditions related to the existence of dangerous (mechanical) conditions fell on average year by year in four first regions in years $2013-2017$ by: $0.30 \%, 0.38 \%, 0.7 \%, 0.8 \%$ respectively and in the fifth increased by $0.63 \%$ (Fig. 3).

\subsection{Econometric analysis}

In this part of the article the attempt was made to explain the number of persons employed in hazardous conditions. The information about the persons employed in hazardous conditions in relation to the ones towards which these threats were eliminated or limited to the level consistent with the norm was used to explain this value. The above discussion was performed in respect to the elimination or limitation due to the strenuous conditions and dangerous (mechanical) conditions because the average tempo of changes (years $2013-2017$ ) reached negative or positive values in various voivodeships under the influence of these factors.

After using the OLS method to estimate equation (1), it was received:

$$
P E i H C_{i t}=\underset{(4,994)}{64,419}-\underset{(1,927)}{3,592} \ln \frac{1}{T W E_{i t}}-\underset{(0,769)}{1,759} \ln T S W_{i t}-\underset{(0,954)}{1,328 \ln T M F_{i t}}
$$

Where: $P E i H C_{i t}$ - persons employed in hazardous conditions for voivodeship $i$ in time $t$; $T W E_{i t}-$ persons employed in harmful conditions in relation to whom the threats related to hazardous conditions were eliminated or limited to the level complying with the norm for voivodeship $i$ in time $t$; TSW $W_{\text {it }}$ - persons employed in hazardous conditions in relation to whom the threats related to strenuous conditions were eliminated or limited to the level complying with the norm for voivodeship $i$ in time $t ; T M F_{\text {it }}$ - persons employed in hazardous conditions in relation to whom the threats related to dangerous (mechanical) conditions were eliminated or limited to the level complying with the norm for voivodeship $i$ in time $t$; $\mathrm{i}=1, \ldots, 16 ; \mathrm{t}=1, . .5$.

On the basis of the equation above, it may be stated that the increase by a unit in the logarithm (threats-cum-persons / 1,000 persons), in which the number of persons employed in hazardous conditions in relation to the harmful conditions occurring in the working environment in relation to whom these threats were eliminated or limited to 
the level consistent with the norm, was raised to power -1 , causes the fall in the number of persons employed in hazardous conditions by $\approx 4$ persons on average. Moreover, the unit increment in the number of persons employed in hazardous conditions in relation to the work strenuousness or dangerous (mechanical) conditions in relation to the ones towards whom these threats were limited during the year are accompanied by smaller and smaller increments of the number of persons employed in hazardous conditions.

In the presented model, the number of observations amounted to 80 , the phenomenon of autocorrelation did not occur $(r=-0.181)$ and the relative error which was made with the use of the estimated model amounted to $8.99 \%$. All explanatory variables were statistically significant and the number of persons employed in hazardous conditions was explained by the model in $96 \%$. The influence of random factors which were not included in the model amounted to $4 \%$.

Taking into consideration shaping the number of persons employed in hazardous conditions depending on the number of persons working in the workstations in relation to whom these threats were eliminated or limited to the level consistent with the norm during the year, it may be noticed that in the case of six voivodeships the explained number of employed persons is over its average level for all Polish voivodeships (Fig. 4).

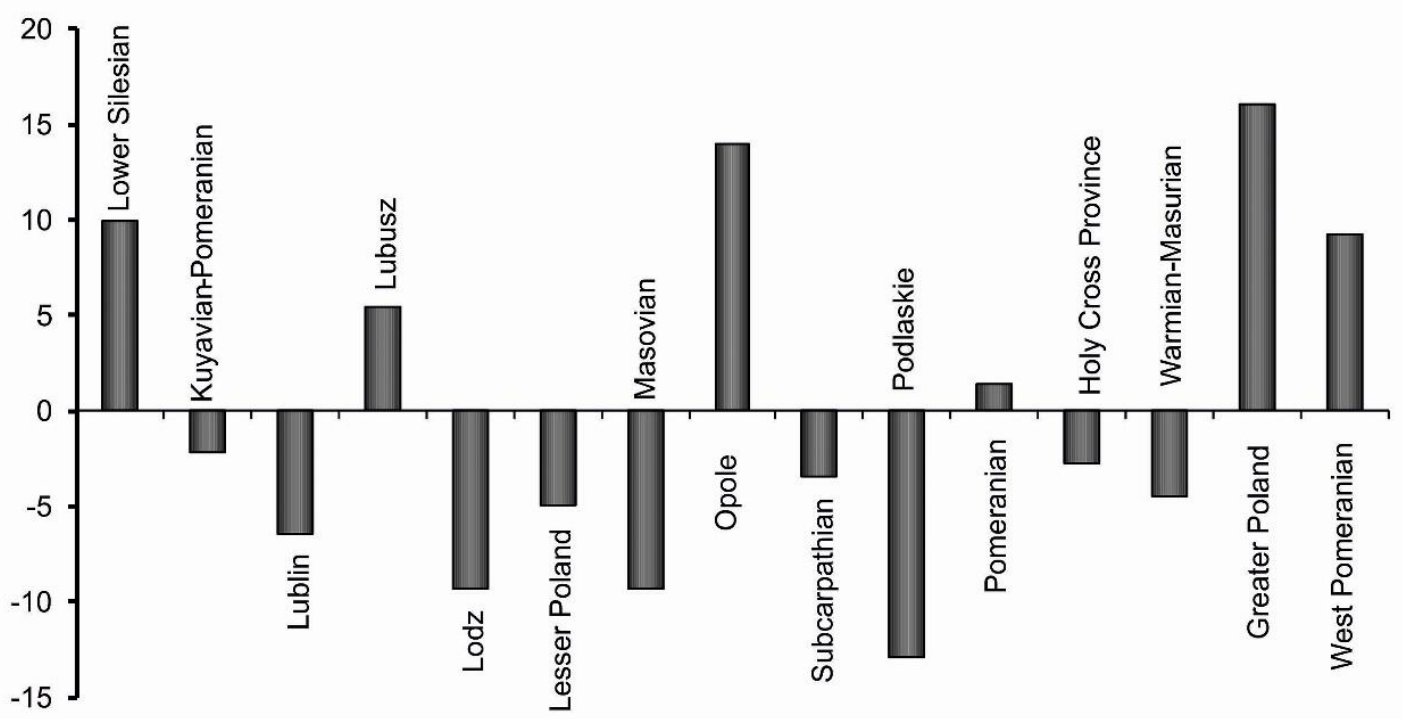

Fig. 4. Differences in the levels of decomposed intercept in the model of the number of persons employed in hazardous conditions

Source: own calculations using the GRETL package, https://bgl.stat.gov.pl/BDL/start

On the basis of the information included in Figure 4, it may be noticed that the number of persons employed in hazardous conditions deviates positively from the average level in Masovian Voivodeship the most and in Pomeranian Voivodeship the least. Whereas these deviations are similar in Opole and Podlaskie Voivodeships but these changes are just opposite.

\section{DISCUSSION}

Ability to work is the main condition, which enables human professional activity. Traditionally the ability to work is defined as the absence of contradictions to perform 
work in the environment in which the particular exposure factors exist. At present, the ability to work is defined as the balance between employee's abilities and the requirements which the work sets. Moreover, this definition is often used as a synonym of human reliability at work, regarded as the efficiency of action.

The ability to work is affected significantly not only by the general health condition (physical health and psychical resources) or possessed competences, knowledge, shared values, attitudes and motivation, but at first the conditions of working environment understood as a set of differentiated material and non-material factors (Tuomi et al., 1998; Ilmarinen, 2005). It should be emphasised that age management constitutes an integral element of the work ability concept (Maltby, 2011). It means that even the healthiest, the most educated and the most involved employees will lose the ability to work if the conditions of working environment exceed their adaptability or their performance. The literature review shows that the ability to work as well as its productivity decreases with age (Vandenberghe et al., 2013), especially there where the work results depend on the employee's physical fitness (Kryńska, 2006; Bortkiewicz and Makowiec-Dąbrowska, 2008). Thus, employing a worker in safe and healthy working conditions prevents premature leave from performed work, contributing to long professional activity, high morale of the staff, creating high quality of life in the workplace.

The analyses conducted in the article show the alarming finding that the highest percentage of respondents complaining on two or more work-related problems was noticed among the persons in the age group 55-59 years old, i.e. the employees ending their professional career. This finding is confirmed by the results of research published by EU-OSHA in which as many as $27 \%$ of employed Europeans expressed the opinion that they would not be able to continue their current work when they would be over 60 years old (Press releases, EU-OSHA). Taking the above into consideration, it should be stated that the promotion of the ability to work (JędrykaGóral et al., 2006), covering the wide range of actions focused both on material conditions of working environment, work contents, physical and psychosocial burden (Bugajska et al., 2005) as well as promotion of healthy lifestyle (Kaleta et al., 2006) and updating professional competences (Oliveira and Cabral-Cardoso, 2017), should be significant among the intervention and repair actions The elements of working environment may affect humans in a work process in some range of values creating work comfort or discomfort. In practice the conditions being hazardous for human health and life in the work process are divided into two basic groups: dangerous mechanical conditions, (traumatic) and harmful and strenuous conditions (Kowal, 2002). The environment in which work process occur "saturates" with various conditions which are not indifferent to an employee. The level of this undesired saturation depends on technological processes, materials used as well as level of hygiene (Uzarczyk, 2006; Wieczorek, 2014). Thus, testing the described factors specifying material working conditions is an important issue from the perspective of threats for human in a work place.

It is optimistic that the number of persons employed in hazardous conditions related to harmful conditions decreased in the analysed five-year-long period, independently of the region of Poland, which is likely to be attributed to legal requirements and regulations. Minimizing or elimination of these threats (generated by harmful conditions which affecting for longer time may lead to occupational diseases) means prevention of premature employee's leave from performed work and thus contributes 
to raising the quality of professional life of each age group of employees. Doing research of shaping the employment in hazardous conditions related to dangerous conditions, (traumatic, causing accidents at work), unfortunately, such a desired phenomenon of permanent fall of this value cannot be noticed in all regions of Poland at the same time. Similarly, the desired positive trend for all regions cannot be distinguished for strenuous conditions.

Interesting findings also result from the analysis of the influence of the number of persons employed in hazardous conditions related to harmful, dangerous strenuous conditions in relation to whom these threats were reduced during the year on the fall in the number of persons employed in hazardous conditions which turned out to be the least beneficial in Greater Poland Voivodeship. Whereas, the situation concerning the improvement of working environment conditions turned out to be the most satisfying in Podlaskie region when it comes to the fall in the number of persons employed in hazardous condition in relation to risk factors. Probably it is strongly connected with the different features of these regions. Wielkopolski industry characterises with the vast majority of small and middle companies, which are leaders in export among SMC sector in Poland. It is possible to distinguish the following industries: pharmaceutical, furniture, lighting equipment and household equipment, ceramic and glass, plastic goods for building industry, tyre, textile and clothing. Also lignite mining, metallurgy and production of energy played an important role (Zarząd Województwa Wielkopolskiego, 2012). Whereas Podlaskie Voivodeship characterises with a bit different features, the indicator of forest cover is higher than the country average, there are numerous forests and the food, wood and machine industry are important in the economy, also tourism plays a significant role (Urząd Marszałkowski Województwa Podlaskiego, 2013).

\section{CONCLUSION}

Working environment constituting an integral part of each company operating determines not only economic results of an organization but also safety, health and the quality of professional life. There are a lot of phenomena and relations, the explanation of which requires to consider various points of view, in the system human being - technical object - surrounding. Its full analysis should include both the issues of work adaptation to a human as well as the issues of human adaptation to work. It is very important due to the fact that the performed discussions confirm that the biggest percentage share of persons suffering from work-related health problems belongs to the group of employees finishing their professional life. Thus, efficient management of work safety and modelling optimal working environment conditions concerning employees' professional careers becomes a desired result of actions promoting the maintenance of the ability to work (to the moment of reaching retirement age).

The performed analyses clearly show that the fall in the employment in hazardous conditions occurred only due to the elimination or limitation of harmful conditions related to the work environment in all voivodeships in the tested period.

It may be concluded from the econometric model that the number of persons employed in hazardous conditions related to all tested risk factors (in relation to the average number of persons employed in hazardous conditions) fell in Podlaskie region the fastest, which should be confirmed in the improvement of work safety level contributing to the higher quality of professional life on employees. 
The research problems presented in the article became the area of research concerning the actions to shape working environment conditions in favour of maintaining the ability to work.

Furthermore, it is necessary to stress that the analyses presented in the work may contribute to further enhanced scientific research contributing to optimising the system human being - technical object - surrounding.

\section{REFERENCES}

Bortkiewicz, A., Makowiec-Dąbrowska, T., 2008. Wiek a zdolność do pracy. [in:] Konsekwencje ekonomiczne i społeczne starzenia się społeczeństwa, ed. Kleer J., Polska Akademia Nauk, Komitet Prognoz „Polska 2000 Plus”, Warszawa.

Bugajska, J., Makowiec-Dąbrowska, T., Jegier, A., Marszałek, A., 2005. Physical work capacity (VO2 max) and work ability (WAl) of active employees (men and women) in Poland. International Congress Series 1280, 156-160. DOI:10.1016/j.ics.2005.03.001

GUS, database-1, Accidents at work and work-related health problems 2014, http://stat.gov.pl (available 28.11.2018).

GUS, database-2, Working conditions in the years 2010-2017, http://stat.gov.pl (available 28.11.2018).

GUS, databases of local branches of the Central Statistical Office, https://bgl.stat.gov.pl/BDL/start (available 28.11.2018).

Ilmarinen, J., 2005. Towards a longer worklife! Ageing and the quality of worklife in the European Union. Finnish Institute of Occupational Health, Helsinki.

Ilmarinen, J., 2012. Promoting active ageing in the workplace. European Year for Active Ageing and Solidarity between Generation 2012, European Agency for Safety and Health at Work.

https://osha.europa.eu/en/tools-and-publications/publications/articles/promotingactive-ageing-in-the-workplace (available 28.11.2018).

Jędryka-Góral, A., Bugajska, J., Łastowiecka, E., Najmiec, A., 2006. Work Ability in Ageing Workers Suffering From Chronic Diseases. International Journal of Occupational Safety and Ergonomics (JOSE), 12(1), 17-30.

Kaleta, D., Makowiec-Dąbrowska, T., Jegier, A., 2006. Lifestyle Index and Work Ability. International Journal of Occupational Medicine and Environmental Health 19(3), 170 - 177, DOI 10.2478/v10001-006-0021-x

Kowal, E., 2002. Ekonomiczno-społeczne aspekty ergonomii, PWN, Warszawa.

Kryńska, E., 2006. Zasoby pracy w Polsce - stan obecny i perspektywy. Starzenie się ludności i zasobów pracy. Konsekwencje i sposoby ich ograniczania, Instytut Pracy i Spraw Socjalnych, Warszawa.

Lund, T., Labriola, M., Christensen, K.B., Bültmann, U., Villadsen, E., 2006. Physical work environment risk factors for long term sickness absence: prospective findings among a cohort of 5357 employees in Denmark. British Medical Journal (BMJ), 25, 332(7539), 449-52. DOI:10.1136/bmj.38731.622975.3A

Maltby, T., 2011. Extending Working Lives? Employability, Work Ability and Better Quality Working Lives. Social Policy \& Society, Cambridge University Press, 10(3), 299-308.

Ng, T.W.H., Feldman, D.C., 2008. The Relationship of Age to Ten Dimensions of Job Performance. Journal of Applied Psychology, 93(2), 392-423. 
Oliveira, E., Cabral-Cardoso, C., 2017. Older workers' representation and age-based stereotype threats in the workplace. Journal of Managerial Psychology, 32(3), 254-268, DOI: https://doi.org/10.1108/JMP-03-2016-0085

Pęciłło, M., 2015. Selected aspects of absence at work and work-related health problems in Polish enterprises. International Journal of Occupational Safety and Ergonomics (JOSE), 21(3), 268-275.

Press releases, EU-OSHA. https://osha.europa.eu/en/about-eu-osha/pressroom/healthy-workplaces-summit-highlights-best-practice-and-policy-solutions (available 28.11.2018).

Takala, J., Hamalainen, P., Saarela, K.L., Yun, L.Y., Manickam, K., Jin, T. W., Heng, P., Tjong, C., Kheng, L.G., Lim, S., Lin, G.S., 2014. Global Estimates of the Burden of Injury and IIIness at Work in 2012. Journal of Occupational and Environmental Hygiene, 11(5), 326-337, DOI: 10.1080/15459624.2013.863131

Tuomi, K., Ilmarinen, J., Jahkola, A., Katajarinne, L., Tulkki, A., 1998. Work Ability Index, 2nd revised ed., Finnish Institute of Occupational Health. Helsinki.

Urząd Marszałkowski Województwa Podlaskiego, 2013. Strategia rozwoju województwa podlaskiego do roku 2020, https://strategia.wrotapodlasia.pl/resource/file/download-file/id.193 (available 28.11.2018).

Uzarczyk, A., 2006. Czynniki szkodliwe i uciążliwe w środowisku pracy. ODDK, Gdańsk.

Vandenberghe, V., Waltenberg, F., Rigo, M., 2013. Ageing and employability. Evidence from Belgian firm-level data. Journal of Productivity Analysis, 40(1), 111-136.

Voss, M., Floderus, B., Diderichsen, F., 2001. Physical, psychosocial, and organisational factors relative to sickness absence: a study based on Sweden Post. Occupational \& Environmental Medicine, 58(3), 178-184, DOI: 10.1136/oem.58.3.178

Wieczorek, S., 2014. Ergonomia. Wydawnictwo TARBONUS, Kraków-Tarnobrzeg.

Zarząd Województwa Wielkopolskiego, 2012. Wielkopolska 2020, Zaktualizowana strategia rozwoju województwa wielkopolskiego do 2020 roku. http://www.wrpo2007-

2013.wielkopolskie.pl/zalaczniki1/2013/Zaktualizowana_Strategia_RWW_do_20 20.pdf (available 28.11.2018). 